\title{
BIOLOGICAL INTEGRITY OF HUGHES CREEK IN THE BITTERROOT RIVER TMDL PLANNING AREA BASED ON THE STRUCTURE AND COMPOSITION OF THE BENTHIC ALGAE COMMUNITY
}

\author{
Prepared for: \\ State of Montana \\ Department of Environmental Quality \\ P.O. Box 200901 \\ Helena, Montana 59620-0901 \\ Project Officer: Andy Welch \\ DEQ Contract No. 200012-10
}

Prepared by:

Loren L. Bahls, Ph.D.

Hannaea

1032 Twelfth Avenue

Helena, Montana 59601

January 31, 2004 
- 


\section{Summary}

On the Fourth of July, 2003, periphyton samples were collected from 2 sites on Hughes Creek in the Bitterroot River TMDL planning area in southwestern Montana for the purpose of assessing whether this stream is water-quality limited and in need of TMDLs. The samples were collected following MDEQ standard operating procedures, processed and analyzed using standard methods for periphyton, and evaluated following modified USEPA rapid bioassessment protocols for wadeable streams.

\section{Diatom metrics at both sites on Hughes Creek indicated excellent biological} integrity, no impairment, and full support of aquatic life uses. However, values for the pollution index at both sites approached the threshold for minor impairment and indicate elevated organic loading. This organic loading may be natural in origin.

A large amount of fine sand was noted in the sample from the lower site on Hughes Creek. However, values for the sedimentation index were well below the threshold for minor impairment in a mountain stream. Nevertheless, both sites did support large numbers of Planothidium lanceolatum, a diatom that is adapted to living on grains of sand.

The diatom and non-diatom algal floras of Hughes Creek indicate moderate gradients and current velocities with little disturbance, and cold, alkaline, and highly oxygenated waters with somewhat elevated levels of organic and inorganic nutrients. Nitrogen is probably the limiting nutrient in this stream. The two sites supported very similar floras, which indicates very similar ecological conditions. Diatom species richness, diversity, and equitability were excellent. No abnormal diatom cells were observed, which indicates the probable absence of toxic chemicals. 


\section{Introduction}

This report evaluates the biological integrity ${ }^{1}$, support of aquatic life uses, and probable causes of stress or impairment to aquatic communities in Hughes Creek in the Bitterroot River TMDL planning area in southwestern Montana. The purpose of this report is to provide information that will help the State of Montana determine whether Hughes Creek is waterquality limited and in need of TMDLs.

The federal Clean Water Act directs states to develop water pollution control plans (Total Maximum Daily Loads or TMDLs) that set limits on pollution loading to water-quality limited waters. Water-quality limited waters are lakes and stream segments that do not meet waterquality standards, that is, that do not fully support their beneficial uses. The Clean Water Act and USEPA regulations require each state to (1) identify waters that are water-quality limited, (2) prioritize and target waters for TMDLs, and (3) develop TMDL plans to attain and maintain water-quality standards for all water-quality limited waters.

Evaluation of aquatic life use support in this report is based on the species composition and structure of periphyton (benthic algae, phytobenthos) communities at two sites on Hughes Creek that were sampled on July 4, 2003. Periphyton is a diverse assortment of simple photosynthetic organisms called algae that live attached to or in close proximity of the stream bottom. Some algae form long filaments or large colonies and are conspicuous to the unaided eye. But most algae, including the ubiquitous diatoms, can be seen and identified only with the aid of a microscope. The periphyton community is a basic biological component of all aquatic ecosystems. Periphyton accounts for much of the primary production and biological diversity in Montana streams (Bahls et al. 1992). Plafkin et al. (1989) and Barbour et al. (1999) list several advantages of using periphyton in biological assessments.

\footnotetext{
'Biological integrity is defined as "the ability of an aquatic ecosystem to support and maintain a balanced, integrated, adaptive community of organisms having a species composition, diversity, and functional organization comparable to that of natural habitats within a region" (Karr and Dudley 1981).
} 


\section{Project Area and Sampling Sites}

The project area is located within the Montana extension of the Idaho Batholith Ecoregion in Ravalli County, Montana. This ecoregion is mountainous, deeply dissected, partially glaciated, and characteristically underlain by granitic rocks. Soils derived from granitics are droughty and have limited fertility, and therefore provide only limited amounts of nutrients to aquatic systems (McGrath et al. 2001). Vegetation in the project area is mixed conifer forest at higher elevations and ponderosa pine, shrubs and grasses at lower elevations (USDA 1976, Woods et al. 1999). The main land uses are logging, grazing, recreation, mining, and wildlife production. Streams in this ecoregion are likely to suffer from increased loads of fine sediments after disturbance by humans. In the Idaho portion of this ecoregion, logging has caused slope instability (especially in granitic areas) and stream sedimentation. Placer gold mining has heavily affected rivers in this ecoregion in the state of Idaho (McGrath et al. 2001).

Periphyton samples were collected at two sites on Hughes Creek (Table 1). Elevation at the sampling sites is about 5,700 feet. Hughes Creek is an east-side tributary of the West Fork of the Bitterroot River upstream from Painted Rocks Reservoir. Hughes Creek and the West Fork of the Bitterroot River are headwater tributaries of the Bitterroot River in USGS hydrologic unit 17010205. The Bitterroot River is a tributary of the Clark Fork River. Hughes Creek is classified B-1 in the Montana Surface Water Quality Standards.

\section{Methods}

Periphyton samples were collected following standard operating procedures of the MDEQ Planning, Prevention, and Assistance Division. Using appropriate tools, microalgae were scraped, brushed, or sucked from natural substrates in proportion to the importance of those substrates at each study site. Macroalgae were picked by hand in proportion to their abundance at the site. All collections of microalgae and macroalgae were pooled into a common container and preserved with Lugol's (IKI) solution. 
The samples were examined to estimate the relative abundance and rank by biovolume of diatoms and genera of soft (non-diatom) algae according to the method described in Bahls (1993). Soft algae were identified using Smith (1950), Prescott (1962, 1978), John et al. (2002), and Wehr and Sheath (2003). These books also served as references on the ecology of the soft algae, along with Palmer $(1969,1977)$.

After the identification of soft algae, the raw periphyton samples were cleaned of organic matter using sulfuric acid, potassium dichromate, and hydrogen peroxide. Then permanent diatom slides were prepared using Naphrax, a high refractive index mounting medium, following Standard Methods for the Examination of Water and Wastewater (APHA 1998). At least 300 diatom cells ( 600 valves) were counted at random and identified to species. The following were the main taxonomic references for the diatoms: Krammer and Lange-Bertalot 1986, 1988, 1991a, 1991b; Lange-Bertalot 1993, 2001; Krammer 1997a, 1997b, 2002; Reichardt 1997, 1999. Diatom naming conventions followed those adopted by the Academy of Natural Sciences for USGS NAWQA samples (Morales and Potapova 2000) as updated in 2003 (Dr. Eduardo Morales, Academy of Natural Sciences, digital communication). Van Dam et al. (1994) was the main ecological reference for the diatoms.

The diatom proportional counts were used to generate an array of diatom association metrics. A metric is a characteristic of the biota that changes in some predictable way with increased human influence (Barbour et al. 1999). Diatoms are particularly useful in generating metrics because there is a wealth of information available in the literature regarding the pollution tolerances and water quality preferences of common diatom species (e.g., Lowe 1974, Beaver 1981, Lange-Bertalot 1996, Van Dam et al. 1994).

Values for selected metrics were compared to biocriteria (numeric thresholds) developed for streams in the Rocky Mountain ecoregions of Montana (Table 2). These criteria are based on metric values measured in least-impaired reference streams (Bahls et al. 1992) and metric values measured in streams that are known to be impaired by various sources and causes of pollution (Bahls 1993). The biocriteria in Table 2 are valid only for samples collected during the summer field season (June 21-September 21). 
The criteria in Table 2 distinguish among four levels of stress or impairment and three levels of aquatic life use support: (1) no impairment or only minor impairment (full support), (2) moderate impairment (partial support), and (3) severe impairment (nonsupport). These impairment levels correspond to excellent, good, fair, and poor biological integrity, respectively. In cold, high-gradient mountain streams, natural stressors will often mimic the effects of mancaused impairment on some metric values.

\section{Quality Assurance}

Several steps were taken to assure that the study results are accurate and reproducible. Upon receipt of the samples, station and sample attribute data were recorded in the Montana Diatom Database and the samples were assigned a unique number, e.g., 2953-01. The first part of this number (2953) designates the sampling site (Hughes Creek above Thunder Mountain Road) and the second part (01) designates the number of periphyton samples that that have been collected at this site for which data have been entered into the Montana Diatom Database.

Sample observations and analyses of soft (non-diatom) algae were recorded in a lab notebook along with information on the sample label. A portion of the raw sample was used to make duplicate diatom slides. The slide used for the diatom proportional count will be deposited in the Montana Diatom Collection at the University of Montana Herbarium in Missoula. The duplicate slide will be retained by Hannaea in Helena. Diatom proportional counts have been entered into the Montana Diatom Database.

\section{Results and Discussion}

Results are presented in Tables 3, 4 and 5, which are located near the end of this report following the references section. Appendix A contains a series of diatom reports, one for each sample. Each diatom report contains an alphabetical list of diatom species in that sample and their percent abundances, and values for 65 different diatom metrics and ecological attributes. 


\section{Sample Notes}

Hughes Creek below first FS gate. Clean sample, little sediment is present.

Hughes Creek above Thunder Mountain Road. Sediment ( 10 micron diameter fine sand) is extremely heavy.

\section{Non-Diatom Algae (Table 3)}

The two sites on Hughes Creek supported very similar algal floras consisting of green algae, cyanobacteria, diatoms, and a chrysophyte. The lower site supported three more genera of non-diatom algae than the upper site. A downstream increase in the number of non-diatom algal genera and diatom species is the normal pattern in mountain streams.

The sample collected at the upper site on Hughes Creek (below first gate on FS parcel) was dominated by a filamentous green alga (Ulothrix) and a branched cyanobacterium with heterocysts (Tolypothrix)(Table 3). These cold-water algae are common in mountain streams. Tolypothrix is capable of fixing atmospheric (molecular) nitrogen, which is an advantage in waters that are poor in nitrogen. Diatoms were abundant at this site and ranked $3^{\text {rd }}$ in biovolume. The chrysophyte Hydrurus foetidus ranked $4^{\text {th }}$ and was rare.

The sample collected at the lower site on Hughes Creek was also dominated by Ulothrix. The cyanobacterium Nostoc ranked $2^{\text {nd }}$ in biovolume here and was a co-dominant with Ulothrix. Like Tolypothrix, Nostoc has heterocysts, is a nitrogen fixer, and prefers cold waters. Diatoms were abundant and ranked $3^{\text {rd }}$ in biovolume at the lower site. Cells of the chrysophyte Hydrurus foetidus, which forms slimy mucilaginous masses, were frequent and this genus ranked $4^{\text {th }}$ in biovolume at this site. Wehr and Sheath (2003) describe Hydrurus foetidus as follows:

One of the most dramatic examples of a cold-water stenotherm is the mountain-stream dwelling chrysophyte Hydrurus foetidus. This macroscopic, brown, gelatinous, unpleasant-smelling alga is relatively abundant in both the eastern and western mountain 
streams of North America. The gelatinous envelope in which the cells are embedded is exceedingly tough and the plant frequently covers the entire surface of submerged rocks and has caused more than one hiker to lose his or her footing when crossing a stream. It normally begins to disappear when water temperatures rise much above $10^{\circ} \mathrm{C} \ldots$ Other requirements for this species apparently include low $\mathrm{pH}$ and bright sunlight.

The nitrogen-fixing cyanophyte Tolypothrix was frequent at the lower site and ranked $5^{\text {th }}$, followed by the branched filamentous green alga Stigeoclonitum, which was also frequent. Stigeoclonium is tolerant of organic pollution and its presence may indicate an increase in organic loading at this site.

\section{Diatoms (Table 4)}

All of the major diatom species from Hughes Creek are included in pollution tolerance classes 3 or 2 , and are either sensitive to organic pollution or only somewhat tolerant of organic pollution (Table 4).

\section{Diatom metrics for both sites on Hughes Creek indicate excellent biological} integrity, no impairment, and full support of aquatic life uses (Table 4). However, pollution index values at both sites (2.53 and 2.54) approached the threshold for minor impairment in a mountain stream (2.50). This slight organic loading may be natural in origin and due to an accumulation of terrestrial plant debris and/or algae. Several of the major diatom species (e.g., Diatoma mesodon, Fragilaria spp., Hannaea arcus, Staurosira construens, Synedra spp.) are free-living and indicate a history of stable flows at these sites and the absence of recent bottomscouring events. These diatoms also indicate cold waters.

Although sedimentation index values did not exceed the threshold for minor impairment at either site, a large amount of fine sand was noted in the sample collected at the lower site (see sample notes, above). This site also had the larger sedimentation index value of the two sites based on the percentage of motile diatoms that were counted. In addition to motile diatoms, these sites supported large numbers of Planothidium lanceolatum, a diatom species that is adapted to living attached to grains of sand. If the percentage of Planothidium lanceolatum at 
these sites is added to the percentage of motile diatoms, sedimentation index values would approach but still not exceed the threshold for minor impairment (Table 4).

Both sites on Hughes Creek supported diatom assemblages with excellent species richness, diversity, and equitability for a mountain stream. The relatively small percentage of Achnanthidium minutissimum at both sites indicates a stream with moderate gradient and current velocity and little physical disturbance. The absence of teratological (abnormal) cells indicates that toxicity from heavy metals is not likely to be a problem here.

As with the non-diatom algae, the two sites on Hughes Creek supported very similar diatom assemblages. The percent community similarity between the two sites was 60.35 , which indicates very similar floras and ecological conditions. Adjacent sites on the same stream without intervening tributaries or point source discharges typically share 60 percent or more of their diatom assemblages (Bahls 1993).

\section{Modal Categories of Ecological Attributes (Table 5)}

Several ecological attributes assigned by Stevenson and Van Dam et al. (1994) were selected from the diatom reports in the appendix and modal categories of these attributes were extracted to characterize water quality tendencies in Hughes Creek (Table 5). Most of the diatoms that inhabit Hughes Creek may be characterized as non-motile, alkaliphilous, and autotrophic, while tolerating high levels of organic nitrogen and a moderate amount of organic loading. They prefer meso-eutrophic to eutrophic, fresh waters, and exert a continuously high demand for dissolved oxygen. These categories are defined by Van Dam et al. (1994). 


\section{References}

APHA. 1998. Standard Methods for the Examination of Water and Wastewater. 20 $0^{\text {th }}$ Edition. American Public Health Association, Washington, D.C.

Balıls, L.L. 1979. Benthic diatom diversity as a measure of water quality. Proceedings of the Montana Academy of Sciences 38:1-6.

Bahls, L.L. 1993. Periphyton Bioassessment Methods for Montana Streams (revised). Montana Department of Health and Environmental Sciences, Helena.

Bahls, L.L., Bob Bukantis, and Steve Tralles. 1992. Benchmark Biology of Montana Reference Streams. Montana Department of Health and Environmental Sciences, Helena.

Barbour, M.T., J. Gerritsen, B.D. Snyder, and J.B. Stribling. 1999. Rapid Bioassessment Protocols for Use In Streams and Wadeable Rivers: Periphyton, Benthic Macroinvertebrates and Fish. Second Edition. EPA/841-B-99-002. U.S. Environmental Protection Agency, Office of Water, Washington, D.C.

Beaver, Janet. 1981. Apparent Ecological Characteristics of Some Common Freshwater Diatoms. Ontario Ministry of The Environment, Technical Support Section, Don Mills, Ontario.

Johansen, J.R. 1999. Diatoms of Aerial Habitats. Chapter 12 in Stoermer, E.F., and J.P. Smol (eds.), The Diatoms: Applications For the Environmental and Earth Sciences, Cambridge University Press, New York.

John, D.M., B.A. Whitton, and A.J. Brook (eds.). 2002. The Freshwater Algal Flora of the British Isles: An Identification Guide to Freshwater and Terrestrial Algae. Cambridge University

Karr, J.R., and D.R. Dudley. 1981. Ecological perspectives on water quality goals. Environmental Management 5:55-69.

Krammer, Kurt. 1997a. Die cymbelloiden Diatomeen: Eine Monographie der weltweit bekannten Taxa. Teil 1. Allgemeines and Encyonema Part. J. Cramer, Berlin.

Krammer, Kurt. 1997b. Die cymbelloiden Diatomeen: Eine Monographie der weltweit bekannten Taxa. Teil 2. Encyonema part., Encyonopsis and Cymbellopsis. J. Cramer, Berlin.

Krammer, Kurt. 2002. Cymbella. Volume 3 in Diatoms of Europe, Horst Lange-Bertalot, ed. A.R.G. Gantner Verlag K.G., Germany.

Krammer, K., and H. Lange-Bertalot. 1986. Bacillariophyceae, Part 2, Volume 1: Naviculaceae. In Ettl, H., J Gerloff, H. Heynig, and D. Mollenhauer (eds.), Freshwater Flora of Middle Europe. Gustav Fischer Publisher, New York.

Krammer, K., and H. Lange-Bertalot. 1988. Bacillariophyceae, Part 2, Volume 2: Bacillariaceae, Epithemiaceae, Surirellaceae. In Ettl, H., J. Gerloff, H. Heynig, and D. Mollenhauer (eds.), Freshwater Flora of Middle Europe. Gustav Fischer Publisher, New York.

Krammer, K., and H. Lange-Bertalot. 1991 a. Bacillariophyceae, Part 2, Volume 3: Centrales, Fragilariaceae, Eunotiaceae. In Ettl, H., J. Gerloff, H. Heynig, and D. Mollenhauer (eds.), Freshwater Flora of Middle Europe. Gustav Fischer Publisher, Stuttgart.

Krammer, K., and H. Lange-Bertalot. 199lb. Bacillariophyceae, Part 2, Volume 4: Achnanthaceae, Critical Supplement to Navicula (Lineolatae) and Gomphonema, Complete List of Literature for Volumes 1-4. In Ettl, H., G. Gartner, J. Gerloff, H. Heynig, and D. Mollenhauer (eds.), Freshwater Flora of Middle Europe. Gustav Fischer Ptiblisher, Stuttgart. 
Lange-Bertalot, Horst. 1979. Pollution tolerance of diatoms as a criterion for water quality estimation. Nova Hedwigia 64:285-304.

Lange-Bertalot, Horst. 1993. 85 new taxa and much more than 100 taxonomic clarifications supplementary to Susswasserflora von Mitteleuropa Vol. 2/1-4. J. Cramer, Berlin.

Lange-Bertalot, Horst. 1996. Rote Liste der limnischen Kieselalgen (Bacillariophyceae) Deutschlands. Schr.-R. f. Vegetationskde., H. 28, pp. 633-677. BfN, Bonn-Bad Godesberg.

Lange-Bertalot, Horst. 2001. Navicula sensu stricto: 10 Genera Separated from Navicula sensu lato; Frustulia. Volume 2 in Diatoms of Europe, Horst Lange-Bertalot, ed. A.R.G. Gantner Verlag K.G., Germany.

Lowe, R.L. 1974. Environmental Requirements and Pollution Tolerance of Freshwater Diatoms. EPA-670/4-74-005. U.S. Environmental Protection Agency, National Environmental Research Center, Office of Research and Development, Cincinnati, Ohio.

McFarland, B.H., B.H. Hill, and W.T. Willingham. 1997. Abnormal Fragilaria spp. (Bacillariophyceae) In streams impacted by mine drainage. Journal of Freshwater Ecology 12(1):141-149.

McGrath, C.L., A.J. Woods, J.M. Omernik, S.A. Bryce, M. Edmondson, J.A. Nesser, J. Shelden, R.C. Crawford, J.A. Comstock, and M.D. Plocher. 2001. Ecoregions of Idaho (color poster with map, descriptive text, summary tables, and photographs). U.S. Geological Survey, Reston, Virginia.

Morales, E.A., and Marina Potapova. 2000. Third NAWQA Workshop on Harmonization of Algal Taxonomy, May 2000. Patrick Center for Environmental Research, The Academy of Natural Sciences, Philadelphia.

Palmer, C.M. 1969. A composite rating of algae tolerating organic pollution. Journal of Phycology 5:78-82.

Palmer, C.M. 1977. Algae and Water Pollution: An Illustrated Manual on the Identification, Significance, and Control of Algae in Water Supplies and in Polluted Water. EPA-600/9-77-036.

Plafkin, J.L., M.T. Barbour, K.D. Porter, S.K. Gross, and R.M. Hughes. 1989. Rapid Bioassessment Protocols for Use in Rivers and Streams: Benthic Macroinvertebrates and Fish. EPA 440-4-89-001.

Prescott, G.W. 1962. Algae of the Western Great Lakes Area. Wm. C. Brown Company, Dubuque, lowa.

Prescott, G.W. 1978. How to Know the Freshwater Algae. Third Edition. Wm. C. Brown Company Publishers, Dubuque, Iowa.

Reichardt, Erwin. 1997. Taxonomische Revision des Artenkomplexes um Gomphonema pumilum (Bacillariophyta). Nova Hedwigia 65(1-4):99-129.

Reichardt, Enwin. 1999. Zur Revision der Gattung Gomphonema. A.R.G. Gantner Verlag, Distributed by Koeltz Scientific Books, Konigstein, Germany.

Renfro, H.B., and D.E. Feray. 1972. Geological Highway Map of the Northern Rocky Mountain Region. American Association of Petroleum Geologists, Tulsa, Oklahoma.

Smith, G.M. 1950. The Fresh-Water Algae of The United States. McGraw-Hill Book Company, New York.

Stevenson, R.J., and Y. Pan. 1999. Assessing Environmental Conditions in Rivers and Streams with Diatoms. Chapter 2 in Stoermer, E.F., and J.P. Smol (eds.), The Diatoms: Applications For the Environmental and Earth Sciences, Cambridge University Press, New York. 
Stewart, W.D.P., P. Rowell, and A.N. Rai. 1980. Symbiotic Nitrogen-Fixing Cyanobacteria. Pp. 239-277 in Stewart, W.D.P., and J. Gallo (eds.), Nitrogen Fixation, Academic Press, New York.

USDA. 1976. Climax Vegetation of Montana (map). U.S. Department of Agriculture, Soil Conservation Service, Cartographic Unit, Portland.

USEPA. 2000. Level III Ecoregions of the Continental United States (map). National Health and Environmental Effects Research Laboratory, U.S. Environmental Protection Agency, Corvallis, Oregon.

Van Dam, Herman, Adrienne Mertens, and Jos Sinkeldam. 1994. A coded checklist and ecological Indicator values of freshwater diatoms from The Netherlands. Netherlands Journal of Aquatic Ecology 28(1):117-133.

Weber, C.1. (ed.). 1973. Biological Field and Laboratory Methods for Measuring the Quality of Surface Waters and Effluents. EPA-670/4-73-001. U.S. Environmental Protection Agency, National Environmental Research Center, Office of Research and Development, Cincinnati, Ohio.

Wehr, J.D., and R.G. Sheath. 2003. Freshwater Algae of North America: Ecology and Classification. Academic Press, New York.

Whittaker, R.H. 1952. A study of summer foliage insect communities in the Great Smoky Mountains. Ecological Monographs 22:1-44.

Woods, A.J., Omernik, J.M., Nesser, J.A., Shelden, J., and S.H. Azevedo. 1999. Ecoregions of Montana (color poster with map), U.S. Geological Survey, Reston, Virginia. 


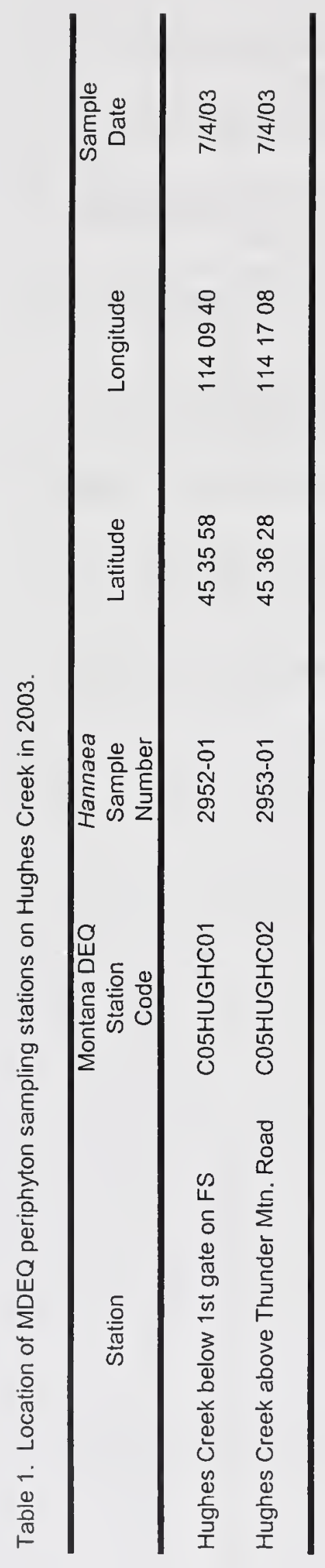




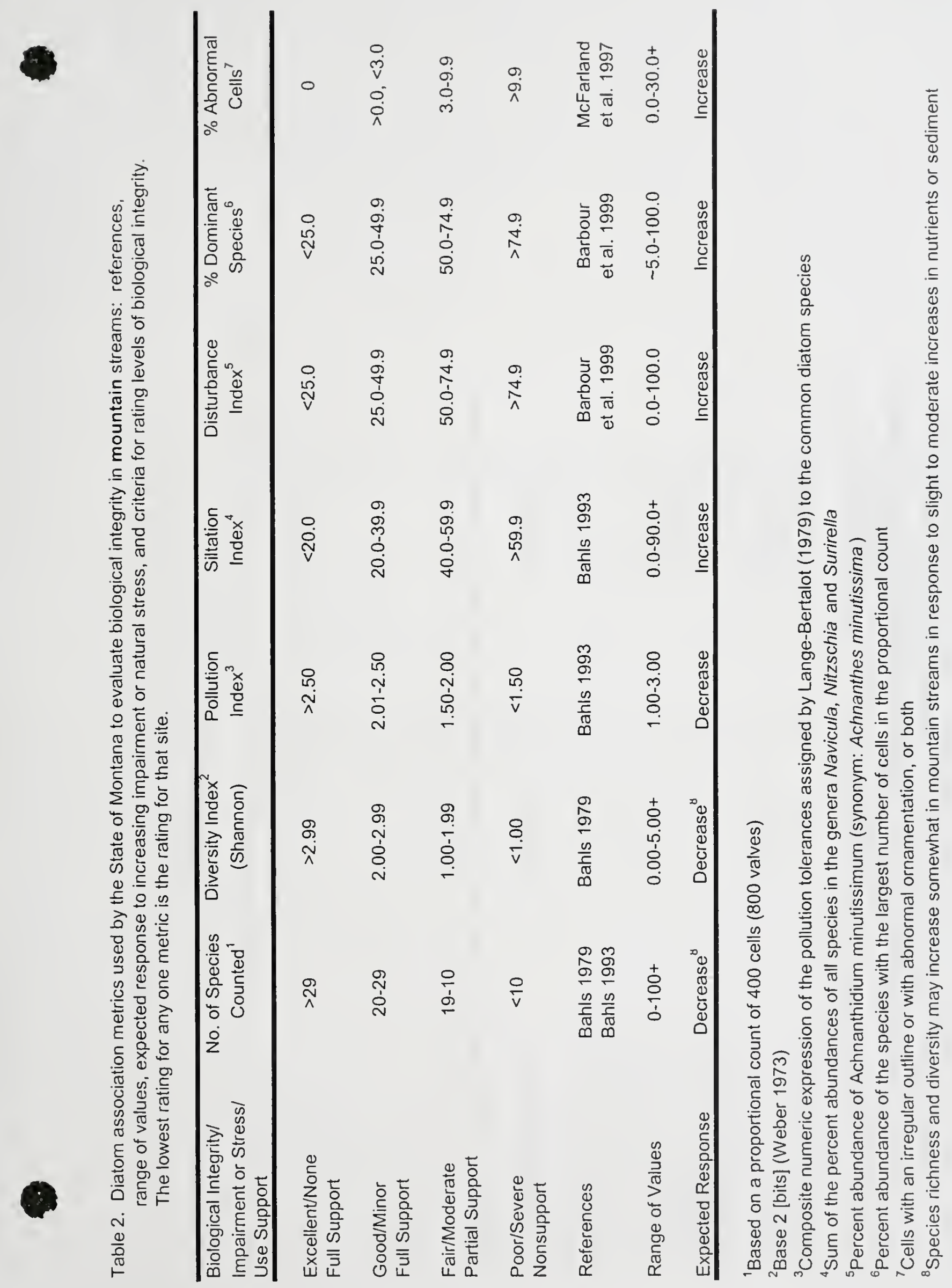




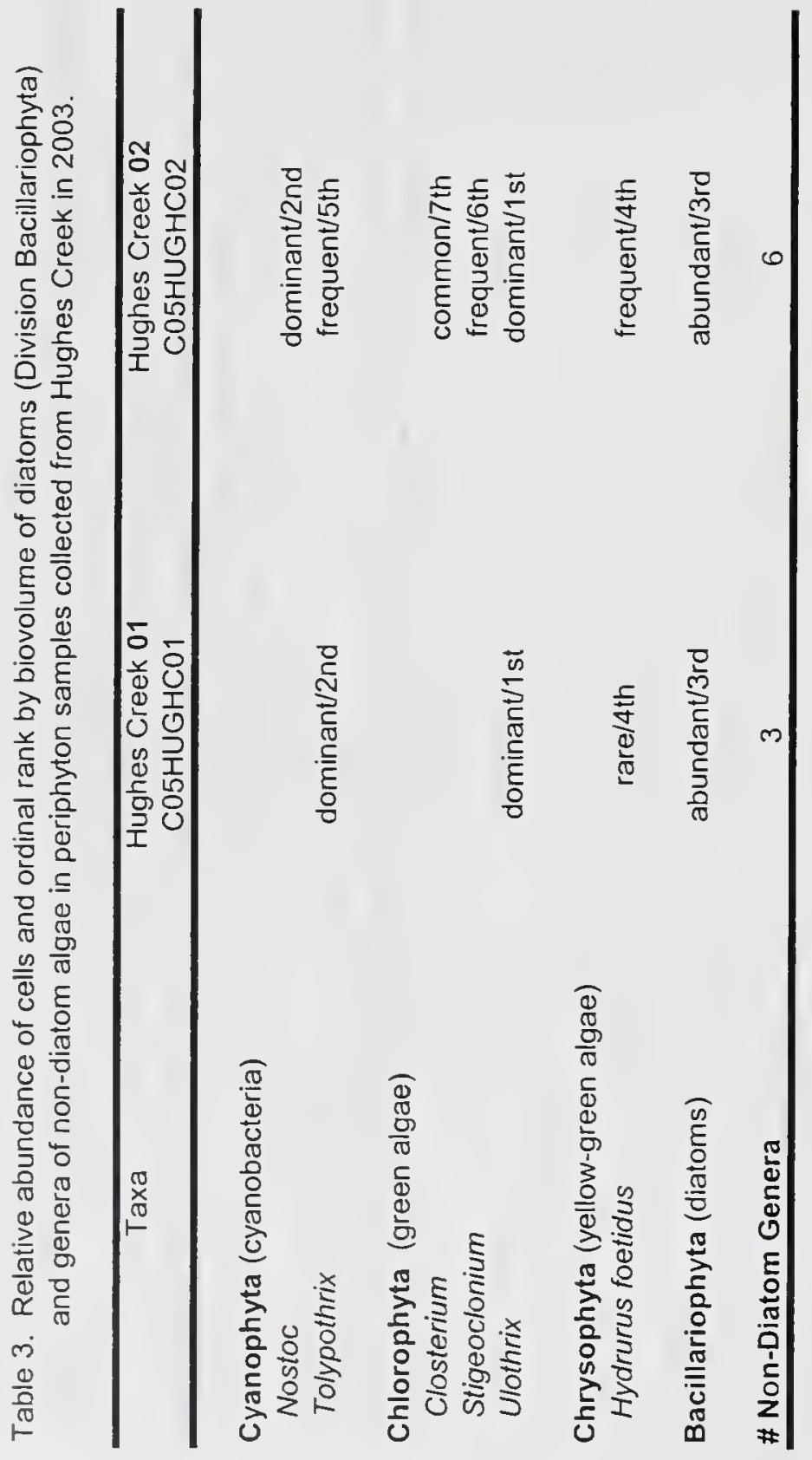




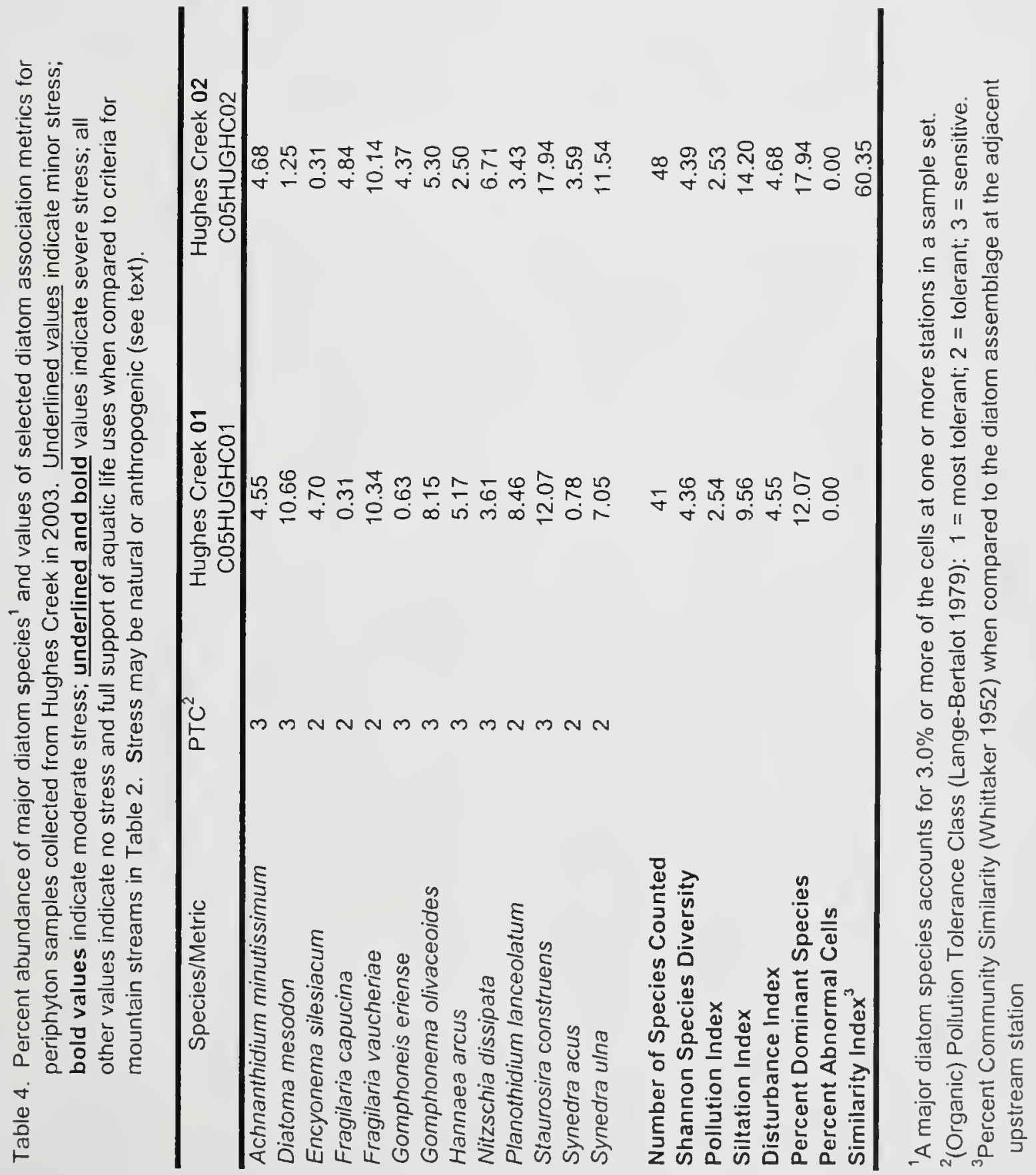




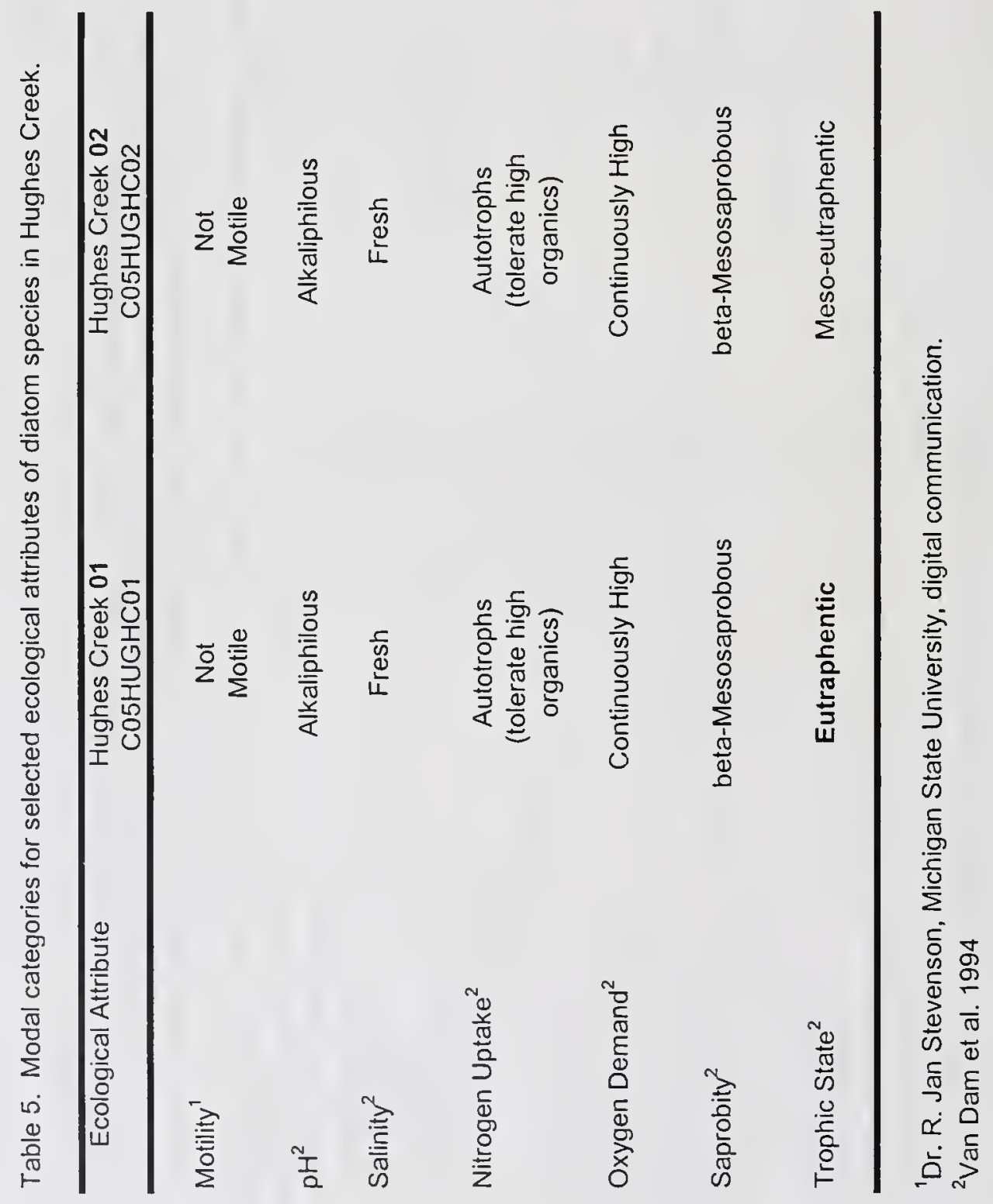

